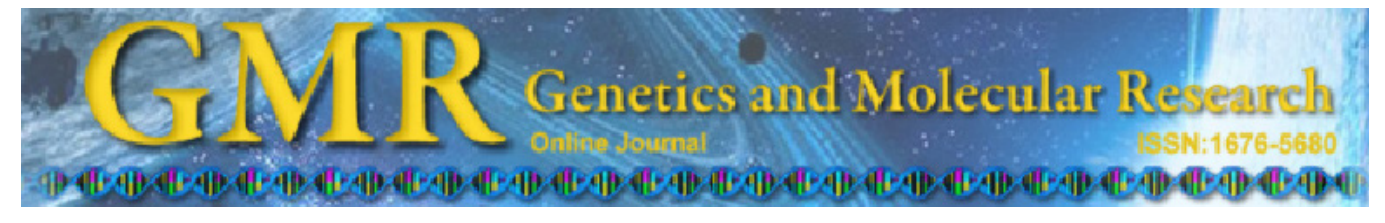

\title{
Factors that influence the test day milk yield and composition
}

\author{
F.G. Silva ${ }^{1}$, L.F. Brito ${ }^{1}$, R.A. Torres ${ }^{1}$, J.I. Ribeiro Júnior ${ }^{2}$, H.R. Oliveira ${ }^{1}$, \\ G.C. Caetano ${ }^{1}$ and M.T. Rodrigues ${ }^{1}$ \\ ${ }^{1}$ Departamento de Zootecnia, Universidade Federal de Viçosa, Viçosa, \\ MG, Brasil \\ ${ }^{2}$ Departamento de Estatística, Universidade Federal de Viçosa, Viçosa, \\ MG, Brasil \\ Corresponding author: F.G. Silva \\ E-mail: felipe.melhoramento@hotmail.com
}

Genet. Mol. Res. 12 (2): 1522-1532 (2013)

Received March 28, 2012

Accepted November 15, 2012

Published May 13, 2013

DOI http://dx.doi.org/10.4238/2013.13.5

\begin{abstract}
The objective of this research was to study the factors that influence the test day milk yield (TDMY) and percentages of protein, fat, lactose, and total dry extract obtained on test day. We evaluated 110,732 weekly milk production records from 1496 goats and 19,271 monthly milk constituent records from 1245 Alpine and Saanen goats, which were collected from 1997 to 2010 in the goat sector at Universidade Federal de Viçosa. To ensure greater record reliability, only lactation data with kidding order between 1 to 6 , type of kidding data including 0 to 3 kids, milk control years after 1997, and genetic groupings other than types 7 or 9 were considered, due to the relative lack of information recorded for some classes of these factors. Data in which the reported milk days were less than 7 or greater than 315 were also eliminated. Goats aged greater than 300 days at calving and those aged less than 6 years at control were considered in this study. Milk production was higher in the dry season in comparison to the rainy season. Genetic grouping did not influence all traits in both breedings. The TDMY tended to increase along with increasing age of the goats at kidding, while the opposite trend was observed relative to
\end{abstract}


kidding order. Factors that significantly influenced all of the studied traits varied, and the factors that significantly influenced each trait were altered between the relationship of Alpine and Saanen breeds. Thus, the analysis of factors that influence traits to be evaluated in the herd under study is critical for defining the best evaluation model.

Key words: Genetic grouping; Season-year; Type of kidding

\section{INTRODUCTION}

Goat milk is an exceptional source of nutrients, which contains more calcium, phosphate, and potassium than cow milk, while containing less cholesterol. In addition, goat milk is associated with lower allergenicity than cow milk due to the lower proportion of the alpha $\mathrm{S}_{\mathrm{S}}{ }^{-}$ casein protein sub-unit. However, despite these advantages, the overall goat milk yield is inferior to that of cow milk, according to data provided by Instituto Brasileiro de Geografia e Estatística (IBGE, 2007). The main reason for this finding is that the cost of goat milk is 3 times greater than that of cow milk.

The principal approach for solving this issue is to reduce production costs. Genetic breeding is an important tool to achieve this goal, although only a few studies have been reported regarding dairy goats.

There are many studies in the literature regarding the choice of fixed effects to include in models evaluating accumulated milk yield (AMY), as described in the reports of Barbosa et al. (1999), Soares Filho et al. (2001), Pereira et al. (2008b), and Brito et al. (2009). Nevertheless, studies evaluating test day milk yield (TDMY) or milk constituents on test day are rare.

Contents of milk constituents are important attributes for the milk industry, inasmuch as they are related to the quantity and quality of milk products. Although there is a relative lack of reports demonstrating that better prices are being paid for milk with higher fat or protein content, it is expected that these traits will benefit the milk industry in the future; by determining the economic value of traits, selection indexes for dairy goat breeding programs will be created. Thus, it is important that breeders contribute to this goal by estimating parameters and selecting the best evaluation models of specific traits, as the study of factors that influence genetic traits is crucial.

The study of factors influencing selectable traits is important for defining the model of genetic evaluation, designing breeding programs and for providing management practice recommendations.

During genetic evaluations, known sources of variations that are not corrected by using fixed effects may influence the residue, thus lowering the accuracy and precision of parameter estimates and the prediction of genetic values of the animals in question. On the other hand, if the inclusion of fixed effects is done improperly, it will contribute to the unnecessary loss of degrees of freedom of the residue, thereby reducing the precision of the results.

Fixed effects can be chosen before genetic evaluation by the general least squares method. Santana Júnior et al. (2008) evaluated the influence of non-genetic effects of kidding season-year (KS-KY), type of kidding (TK), kidding order (KO), control month, days in milk (DIM), and the age of the goat at kidding (AGK) on milk production and the percentages of the milk components. TK was the factor that did not influence milk production, indicating that the other aforementioned factors should be included in other models of TDMY evaluation. 
The objective of this study was to identify factors that influence the TDMY and milk components on test day in Alpine and Saanen goats.

\section{MATERIAL AND METHODS}

We evaluated 110,732 weekly milk production records from 1496 goats and 19,271 monthly milk constituent records from 1245 Alpine and Saanen goats, which were collected from 1997 to 2010 in the goat sector at Universidade Federal de Viçosa (UFV, MG). The goats used in the experiment belonged to different Alpine and Saanen genetic groupings. The animals were raised in a free stall system and were fed corn silage- and hay-based diets (as roughage) in a concentrated mixture given according to their nutritional needs.

Milk controls were performed weekly in a milking machine, twice a day. The morning collection began at 6:00 am, and the afternoon collection began at 2:00 pm The TDMY values were derived from the sum of milk collected during both periods. Sample collection for analysis of milk components was conducted monthly, and the contents were analyzed at the Milk Quality Laboratory in the Departamento de Zootecnia at UFV.

The variables that were assessed and their respective classifications were as follows: kidding year (from 1997 to 2010); season (1 from March to September and 2 for the remaining months); KO (from 1 to 10); TK (from 0 to 4 kids); and genetic grouping $(90 \%<$ Alpine $=1$; $80 \%<$ Alpine $\leq 90 \%=2 ; 70 \%<$ Alpine $\leq 80 \%=3 ; 60 \%<$ Alpine $\leq 70 \%=4 ; 50 \%<$ Alpine $\leq 60 \%=5 ; 90 \%<$ Saanen $=6 ; 80 \%<$ Saanen $\leq 90 \%=7 ; 70 \%<$ Saanen $\leq 80 \%=8$; and $60 \%$ $<$ Saanen $\leq 70 \%=9 ; 50 \%<$ Saanen $\leq 60 \%=10)$. The continuous variables that were assessed included the AGK covariables (with linear and quadratic effects) and DIM (with linear, quadratic, and cubic effects).

To increase the reliability of the records, data were considered only for records that included lactation with $\mathrm{KO}$ between 1 to 6 , TK data including 0 to 3 kids, control year higher than 1997, and genetic groupings other than 7 or 9, as little information was provided for some classes of these factors. We also eliminated data from goats whose DIM was less than 7 (colostrum period) and greater than 315 , which is a high value to cover all time periods cited in relevant literature studies of goats. Data from goats with AGK higher than 300 days and the age of goat on test day (AGTD) lower than 6 years were included.

After including these restrictions, 80,486 TDMY records of 1200 goats and 13,351 records of each milk component of 994 goats were analyzed in the present study. This file was regarded as the complete file (CF). Two separate files were created from the $\mathrm{CF}$, the first contained animals comprised of greater than $50 \%$ of the Alpine breed (A) and the other contained those comprised of greater than 50\% of the Saanen breed (S). File A contained 50,347 TDMY records and 9971 records of each milk component, whereas file S contained 30,139 and 3380 records, respectively. The model used to test the influence of the aforementioned factors on the TDMY was as follows:

$$
\begin{aligned}
y_{i j k l m n}=\mu+ & O_{i}+T_{j}+G_{k}+S_{l}+Y_{m}+S x Y_{l m}+b_{1}\left(P_{i j k l m n}-\bar{P}\right) \\
& +b_{2}\left(P_{i j k l m n}-\bar{P}\right)^{2}+c_{1}\left(D_{i j k l m n}-\bar{D}\right)+c_{2}\left(D_{i j k l m n}-\bar{D}\right)^{2} \\
& +c_{3}\left(D_{i j k l m n}-\bar{D}\right)^{3}+\varepsilon_{i j k l m n}
\end{aligned}
$$


where

$\mathrm{y}_{\mathrm{ijklmn}}=$ observed value of the analyzed trait (TDMY and percentage of protein, fat, lactose, and total dry extract) in the $n$ goat, $i \mathrm{KO}, j \mathrm{TK}, k$ genetic grouping, $l$ season, $m$ year;

$\mu=$ mean of the analyzed trait;

$O_{i}=$ fixed effect of $i \mathrm{KO}$;

$T_{j}=$ fixed effect of $j \mathrm{TK}$;

$G_{k}=$ fixed effect of $k$ genetic grouping;

$S_{l}=$ fixed effect of $l$ kidding season;

$Y_{m}=$ fixed effect of $m$ kidding year;

$S \times Y_{l m}=$ effect of interaction between season and control year;

$b_{1}$ and $b_{2}=$ linear and quadratic effects of the trait analyzed as a function of AGK;

$P_{i j k l m n}=$ mean age of the goat at kidding relative to $n$ measurement;

$\bar{P}=$ mean age of the goat at kidding mean;

of DIM;

$c_{1}, c_{2}$, and $c_{3}=$ linear, quadratic and cubic effects of the trait analyzed as a function

$D_{i j k l m n}=$ DIM during $n$ measurement;

$\bar{D}=$ mean of DIM;

and $\varepsilon_{i j k l m n}=$ residue.

Statistical analyses were performed by the general least square method by using the generalized linear model (PROC GLM) procedure of the Statistical Analysis System program (SAS, 2003, SAS Institute Inc., Cary, NC, USA).

\section{RESULTS AND DISCUSSION}

Table 1 presents the number of observations, means, standard deviation, and coefficients of variation for the TDMY and for the percentages of the milk components, protein, fat, lactose, and total dry extract. The presented values are within the acceptable values for dairy goats. The mean TDMY for Saanen goats was below $2.7 \mathrm{~kg} / \mathrm{day}$, as described by Tholon et al. (2001), in the southeastern Brazil region. This indicates that higher values might be reached by improving the analyzed herd. The mean values of protein, fat, and lactose percentages were similar to those reported by Prata et al. (1998), who worked with Saanen goats in southeastern Brazil; they obtained values of $3.27,3.74$, and $4.35 \%$, respectively.

\begin{tabular}{|c|c|c|c|c|c|c|c|c|c|c|c|c|}
\hline \multirow[t]{2}{*}{ Trait } & \multicolumn{3}{|c|}{ Number } & \multicolumn{3}{|c|}{ Mean } & \multicolumn{3}{|c|}{ SD } & \multicolumn{3}{|c|}{$\mathrm{CV}$} \\
\hline & A & AS & $\mathrm{S}$ & A & AS & $\mathrm{S}$ & A & AS & $\mathrm{S}$ & A & AS & $\mathrm{S}$ \\
\hline TDMY & 50347 & 80486 & 30139 & 2.12 & 2.00 & 1.79 & 1.13 & 1.07 & 0.92 & 53.15 & 53.46 & 51.64 \\
\hline PRO & 9971 & 13351 & 3380 & 3.16 & 3.15 & 3.13 & 0.46 & 0.44 & 0.37 & 14.64 & 14.00 & 11.85 \\
\hline FAT & 9971 & 13351 & 3380 & 3.40 & 3.50 & 3.78 & 0.94 & 0.98 & 1.03 & 27.49 & 27.88 & 27.32 \\
\hline LAC & 9971 & 13351 & 3380 & 4.41 & 4.37 & 4.25 & 0.40 & 0.40 & 0.37 & 9.01 & 9.07 & 8.62 \\
\hline TDE & 9971 & 13351 & 3380 & 11.85 & 11.90 & 12.07 & 1.28 & 1.29 & 1.31 & 10.80 & 10.84 & 10.84 \\
\hline
\end{tabular}


The scientific community tends to consider distinct breeds as different genetic entities and performs genetic evaluations separately, even when there are related animals among distinct breeds. This practice occurs because most farmers aim to maintain the breed pattern, which is noted in the pedigree records provided by goat farmer associations. In addition, joint evaluation may impair manufacturing and use of the majority of reproducers. However, some farmers may be interested in working with crossbred animals, which increases genetic variability of the herd and promotes genetic advantages such as heterosis. Therefore, our analyses of the Alpine and Saanen breeds were performed both jointly and separately.

Table 2 presents the results of analysis of the factors [TK, KO, genetic grouping (GG), $\mathrm{KS}, \mathrm{KY}, \mathrm{KS} * \mathrm{KY}$, AGK, and DIM] that influence each of the assessed traits (TDMY, protein, fat, lactose, and total dry extract) for Alpine and Saanen goats, both jointly and separately analyzed.

\begin{tabular}{|c|c|c|c|c|c|c|c|c|c|c|c|c|c|c|c|}
\hline \multirow[t]{3}{*}{ Effects } & \multicolumn{15}{|c|}{ Trait } \\
\hline & \multicolumn{3}{|c|}{ TDMY } & \multicolumn{3}{|c|}{ PRO } & \multicolumn{3}{|c|}{ FAT } & \multicolumn{3}{|c|}{ LAC } & \multicolumn{3}{|c|}{ TDE } \\
\hline & A & AS & $\mathrm{S}$ & A & AS & $\mathrm{S}$ & A & AS & $\mathrm{S}$ & A & AS & $S$ & A & AS & $\mathrm{S}$ \\
\hline Type of kidding & $*$ & * & $*$ & $*$ & $*$ & $*$ & $*$ & * & $*$ & ns & $*$ & $*$ & * & $*$ & $*$ \\
\hline Kidding order & $*$ & $*$ & $*$ & $*$ & $*$ & $*$ & $*$ & $*$ & $*$ & $*$ & $*$ & $*$ & $*$ & $*$ & $*$ \\
\hline Genetic grouping & ns & $*$ & $*$ & ns & $*$ & ns & $*$ & * & $\mathrm{ns}$ & ns & * & ns & * & ns & ns \\
\hline Season of year & $*$ & $*$ & $*$ & $*$ & $*$ & $*$ & $*$ & $*$ & $*$ & $*$ & $*$ & ns & $*$ & $*$ & $*$ \\
\hline Year of kidding & * & * & * & * & * & * & * & * & * & * & * & * & * & * & * \\
\hline $\mathrm{SY} \mathrm{Y}^{*} \mathrm{YK}$ & $*$ & * & $*$ & $*$ & $*$ & * & $*$ & $*$ & $*$ & $*$ & * & $*$ & * & $*$ & $*$ \\
\hline AGK (linear) & $*$ & $*$ & ns & ns & $\mathrm{ns}$ & * & ns & ns & ns & $\mathrm{ns}$ & $\mathrm{ns}$ & ns & * & $*$ & $*$ \\
\hline AGK (quadratic) & $*$ & $*$ & $*$ & ns & ns & * & ns & $*$ & ns & ns & ns & ns & * & $*$ & $*$ \\
\hline DIM (linear) & ns & ns & ns & $*$ & $*$ & $*$ & $*$ & $*$ & $*$ & $*$ & $*$ & $*$ & * & $*$ & $*$ \\
\hline DIM (quadratic) & $*$ & $*$ & $*$ & $*$ & $*$ & $*$ & $*$ & $*$ & * & $\mathrm{ns}$ & $*$ & $*$ & * & $*$ & $*$ \\
\hline DIM (cubic) & $*$ & $*$ & $*$ & $*$ & $*$ & * & $*$ & * & $*$ & ns & ns & $*$ & * & $*$ & $*$ \\
\hline
\end{tabular}

$\mathrm{SY} * \mathrm{YK}=$ interaction between season of year and year of kidding; AGK = age of the goat at kidding; DIM $=$ days in milk. For other abbreviations, see legend to Table 1 . ${ }^{*}$ Significant at $5 \%$ probability; ns $=$ non-significant.

Many factors that may influence milk production were described by Barbosa et al. (1999), and KY, KS, age of the cow at kidding, GG, length of the lactation period, and the bull are the most factors studied. Other factors such as calf sex, origin of the reproducer, variety of hair, and cause of the end of lactation are the least studied factors. In cattle, the sex of the offspring is the most studied factor. In goats, kidding with 2 to 3 kids occurs frequently, thus the TK is the most commonly studied factor, which corresponds to the number of animals born alive.

The length and cause of lactation end may be tested when accumulated milk production is analyzed, although these factors are not included when the TDMY is considered. Vasconcellos et al. (2003), working with AMY in crossbred cattle, created a lactation length classification. However, including lactation length in the evaluation of our model may not be appropriate since the random relationship between these 2 traits may not exist; furthermore, both traits are influenced by the same factors, which should be included in the model.

Milk somatic cell count is an important indicator of milk quality and the health of the udders, and is a trait that is used by some companies for determining the milk payment. However, Pereira et al. (2008a) found heritability estimates for this trait equal to nil. Thus, milk somatic cell count will be reduced by improving management practices insofar as gains by genetic improvement are not expected; therefore, this trait was not included in the present study. 
Silva et al. (2009) found effects of breed (Toggenburg, crossbreeds, Alpine, Saanen, and American Alpine) and kidding year (2004 to 2008) on TDMY, although they did not find an effect because of the kidding order. Nevertheless, these results should be carefully regarded because of the small number of animals and a large variance among effect classes.

Other factors such as AGTD and the age of the goat in the herd may influence milk production on the TDMY; however, these factors were not evaluated since they explain the same variation of other factors that were jointly analyzed. AGTD cannot be used in the AMY analysis, but for TDMY, the variation of this factor may be explained by AGK and DIM, together. Variation of TDMY, as accounted for by age of the goat in the herd, can be compared to the variation due to AGK, DIM and the contemporaneous group.

Kidding order, AGK and AGTD presented influence overlapping on the traits analyzed, and it is not recommended to use more than one of these factors in the same analysis. Overall, it is expected that kidding order promotes less correction of non-genetic deviations in relation to AGK, which presents wider and more modulated correction capacity, in addition to being related to kidding order. It is also expected that AGTD is a better correction factor than AGK in the analysis of test day production, because in addition to representing age at kidding, this value is added to days in milk, which indicates the variations within lactation period. However, a better correction and contrast is expected by using lactation days, which is used as a test variable in random regression models. In this example, AGTD should not be used since it would impair analysis by correcting a part of the effect of the test variable.

Table 2 shows the occurrences of alterations in the factors significantly influencing the studied traits in relation to Alpine and Saanen goats. This indicated problems in evaluating animals of both breeds together and that the fixed effects used in the evaluations of these 2 breeds were distinct.

Effects of KY and KS and their interaction were significant for all traits, showing that these effects should be included in the model. However, these effects may be combined, which may reduce multicolinearity of the incidence matrix for fixed effects in the genetic evaluations using mixed model methodology, while also reducing its dimension and the number of parameters to be estimated, thus facilitating the solving of the equation systems. The yearseason effect is associated with climate alterations and variations in the diets of the animals. According to Brito et al. (2009), variation in rainfall between and in the studied years causes variations in the performance through seasonality of feed availability, both in qualitative and quantitative terms.

The creation of the variable year-season generally occurs according to the traditional calculation exemplified in Figure 1, but in this system, there is the inconvenience that information collected in the rainy season at the beginning of a year is joined with the information collected in the rainy season at the end of the year. A season presents more specific characteristics than a year; thus, the years should be divided and not the seasons. In the alternative calculation, season is seen as a priority in relation to the year, as exemplified in Figure 1.

Correlations among the traits analyzed are expressed in Table 3; for Alpine goats, above the main diagonal, and for Saanen goats, below the main diagonal. Overall, it can be noted that there were no differences of great magnitude among correlations, showing that the relationship among traits follows the same tendency in both breeds. Negative correlations between TDMY and contents of protein, fat, and total dry extract show that increased TDMY does not imply a proportional increase of all milk components with the occurrence of a dilution effect of some components in the milk causing reduction in the percentages. The high 
correlation between fat and total dry extract exists because fat is the largest and most variable component in the total dry extract thus a dependence relationship exists.

\section{Traditional Calculation:}

a) Animal $=A$, Month $=$ February, Year $=2005$, Season $=1$, Season- Year $=20051$ or 1 ;

b) Animal = B, Month $=$ December, Year $=2005$, Season $=1$, Season-Year $=20051$ or 1;

c) Animal $=$ C, Month $=$ January, Year $=2006$, Season $=1$, Season- Year $=20061$ or 3 .

\begin{tabular}{|c|c|c|c|c|}
\hline \multicolumn{3}{|c|}{ Year 2005 } & \multicolumn{3}{c|}{ Year 2006 } \\
\hline Season I & Season II & Season I & Season II & Season I \\
\hline
\end{tabular}

A

\section{Alternative Calculation:}

a) Animal $=A$, Month $=$ February, Year $=2005$, Season $=1$, Season- $Y e a r=1$;

b) Animal $=B$, Month $=$ December, Year $=2005$, Season $=1$, Season- Year $=3$;

c) Animal $=$ C, Month $=$ January, Year $=2006$, Season $=1$, Season- Year $=3$.

\begin{tabular}{|l|c|c|c|c|}
\hline \multicolumn{3}{|c|}{ Year 2005 } & \multicolumn{3}{c|}{ Year 2006 } \\
\hline Season I & Season II & Season I & Season II & Season I \\
\hline
\end{tabular}

Figure 1. Tradition and alternative design year-season variable estimate.

Table 3. Phenotypic correlation between the traits analyzed for Alpine (above main diagonal) and Saanen goats (below the main diagonal).

\begin{tabular}{lcccrr}
\hline & TDMY & PRO & FAT & LAC & TDE \\
\hline TDMY & - & -0.21 & -0.17 & 0.21 & -0.15 \\
PRO & -0.21 & - & 0.35 & 0.00 & 0.58 \\
FAT & -0.15 & 0.25 & - & - & 0.89 \\
LAC & 0.31 & -0.09 & 0.09 & 0.34 & 0.27 \\
TDE & -0.09 & 0.47 & 0.92 & - \\
\hline
\end{tabular}

For abbreviations, see legend to Table 1.

Tables 4, 5, 6, and 7 present mean test results of the TDMY trait as a function of the factors of KO, TK, season of the year, control year and GG, respectively, by using the CF. The expressed results are interesting, since they help to increase our understanding of the herd and our understanding of the manner in which different factors affect production, in order to allow for better control of environmental variation. 
Table 4. Mean test of the best day milk yield in function of kidding order (KO), using Alpine and Saanen breed file.

\begin{tabular}{lrr}
\hline KO & Number & Mean \\
\hline 1 & 35007 & $2.03^{\mathrm{a}}$ \\
2 & 23108 & $2.02^{\mathrm{a}}$ \\
3 & 13383 & $1.98^{\mathrm{a}}$ \\
4 & 5902 & $1.86^{\mathrm{b}}$ \\
5 & 2525 & $1.86^{\mathrm{b}}$ \\
6 & 561 & $1.68^{\mathrm{c}}$ \\
\hline
\end{tabular}

Means followed by the same letters do not differ from each other by the Tukey test at $5 \%$ probability.

Table 5. Mean test of the best day milk yield in function of kidding type (TK) by using Alpine and Saanen breed file.

\begin{tabular}{lcc}
\hline TK & Number & Mean \\
\hline 0 & 7035 & $2.82^{\mathrm{a}}$ \\
1 & 35880 & $1.86^{\mathrm{d}}$ \\
2 & 34233 & $1.96^{\mathrm{c}}$ \\
3 & 3338 & $2.14^{\mathrm{b}}$ \\
\hline
\end{tabular}

Means followed by the same letter do not differ from each other by the Tukey test at $5 \%$ probability.

Table 6. Mean test of the best day milk yield in function of the season by using Alpine and Saanen breed file.

\begin{tabular}{lcr}
\hline Season & Number & Mean \\
\hline Dry & 35685 & 2.06 \\
Rainy & 44801 & 1.95 \\
\hline
\end{tabular}

Means differ statistically from each other at the level of $5 \%$ of significance by the $F$-test.

Table 7. Mean test of the best day milk yield in function of measurement year by using Alpine and Saanen breed file.

\begin{tabular}{lcr}
\hline Year & Number & Mean \\
\hline 1998 & 2434 & $2.43^{\mathrm{b}}$ \\
1999 & 5029 & $3.26^{\mathrm{a}}$ \\
2000 & 3854 & $2.34^{\mathrm{c}}$ \\
2001 & 5301 & $2.27^{\mathrm{d}}$ \\
2002 & 7913 & $2.00^{\mathrm{f}}$ \\
2003 & 7941 & $1.79^{\mathrm{g}}$ \\
2004 & 6610 & $1.65^{\mathrm{h}}$ \\
2005 & 6885 & $1.58^{\mathrm{i}}$ \\
2006 & 8406 & $1.58^{\mathrm{i}}$ \\
2007 & 7845 & $2.01^{\mathrm{ef}}$ \\
2008 & 7830 & $2.02^{\mathrm{ef}}$ \\
2009 & 7427 & $2.07^{\mathrm{e}}$ \\
2010 & 3011 & $1.76^{\mathrm{g}}$ \\
\hline
\end{tabular}

Means followed by the same letters do not differ from each other by the Tukey test at $5 \%$ probability.

According to Ribeiro (1997), the smallest milk yield occurs during the first lactation, which can increase until the goat reaches 4 or 5 years of age, corresponding to the third and fourth kiddings. This age-associated increase in milk yield can be attributed to the physiological growth that occurs up to adult life. Since younger animals' nutritional needs are directed to perform 3 functions, growth, lactation, and maintenance, the organic, digestive, cardiorespiratory capacities, and functioning of the mammary gland are completely developed in adult ani- 
mals. In this phase, nutrition fuels the processes of maintenance, reproduction, and production (Carvalho et al., 2001).

Nevertheless, the results found in this study diverge from this philosophy, and might be related to caprine arthritis-encephalitis, which sometimes afflicts animals in the herd analyzed; caprine arthritis-encephalitis disease is remedied by treating milk and separating the animals by age group. Artificial insemination practices, separation of goats in production phase according to lactation order, and milking young goats before others represent some of the practices that may reduce the incidence of this disease in a herd.

Although kids are separated from their nanny goats immediately after kidding, the effect of TK influenced all of the traits. The possible causes are linked to fetus development in contrast to hormonal stimulation, which varies according to the number of fetuses present. According to Sands and McDowell (1978), TK may affect future milk production since it is related to the placental lactogen, progesterone, and prolactin hormones, which circulate during gestation, stimulate the mammary gland, and differ in quantity according to the type of gestation.

The greatest milk production of goats that did not kid any live offspring may be associated with the unneeded nutrition of the fetus at the initial stage of gestation, a period in which more nutrition is required for the goat, and partial uterine reabsorption of the fetus may occur. The phenomenon may also be associated with the fact that a 0 kidding gestation type occurs more frequently in primiparous goats, which presented greater milk production in this herd.

The season variable was created based on separating production records into 2 periods of the year, the rainy season and the dry season. According to pluviometric and temperature data for Viçosa, obtained by Rodrigues et al. (2010), the best division would be from April to September for the dry season, and in the other months in the year for the rainy season. This division significantly influenced all traits, with the exception of lactose in Saanen goats.

As shown in Table 6, milk production was highest in the dry season relative to the rainy season. This result may be linked to the greater occurrence of diseases such as mastitis and lymphadenitis in the rainy season due to the higher humidity and temperature, which favors pathogens. Barbosa et al. (1999), working with AMY, also found higher results for milk production of goats that delivered kids in the dry season. Since the highest milk production occurs close to the kidding time and goats are more sensitive during the lactation peaks, it is believed that the reasons for the difference in milk production are the same.

The results obtained in the Table 7 indicate that breeding and herd management practices are not achieving satisfactory results. It should be noted that it is critical to develop more studies regarding genetic breeding of dairy goats.

Genetic grouping did not influence all of the traits in both breeds. Brito et al. (2009) found a significant genetic grouping effect only for fat percentage. The authors attributed the result to the fact that most animals were specialized on milk yield (Alpine and Saanen).

Table 8 shows interesting results regarding heterosis of animals with a breed degree close to 3/4 Alpine and 9/16 Alpine, although these results should be treated carefully since they might be influenced by the numerous unbalanced factors acting on TDMY.

Table 8 also indicates that Alpine goats produced more milk than Saanen goats, contradicting most reports in the literature that describes Saanen goats as the most productive breed. Barbieri et al. (1990) found TDMY values of 2.3 and $1.6 \mathrm{~kg}$ /day for Saanen and Alpine goats, respectively, in the northeastern Brazil region. Soares Filho et al. (2001) reported 
TDMY values of 2.34, 2.01, and $1.7 \mathrm{~kg}$ /day for Saanen, Alpine, and Toggenburg goats, respectively, in Distrito Federal, Brazil. These results may be related to the genetic material of the acquired Alpine breed being better than that of the Saanen breed or to better adaptation of the Alpine breed to the local conditions.

Table 8. Mean test of the best day milk yield in function of the breed by using Alpine and Saanen breed file.

\begin{tabular}{clrr}
\hline Breed & Description & Number & Mean \\
\hline 1 & Alpine $>90 \%$ & 22856 & $2.01^{\text {cd }}$ \\
2 & $90 \% \geq$ Alpine $>80 \%$ & 11374 & $2.17^{\mathrm{b}}$ \\
3 & $80 \% \geq$ Alpine $>70 \%$ & 7783 & $2.31^{\mathrm{a}}$ \\
4 & $70 \% \geq$ Alpine $>60 \%$ & 3609 & $1.94^{\mathrm{d}}$ \\
5 & $60 \% \geq$ Alpine $>50 \%$ & 4725 & $2.36^{\mathrm{a}}$ \\
6 & Saanen $>90 \%=6$ & 26797 & $1.77^{\mathrm{f}}$ \\
8 & $80 \% \geq$ Saanen $>70 \%$ & 1212 & $1.86^{\mathrm{f}}$ \\
10 & $60 \% \geq$ Saanen $>50 \%$ & 2130 & $1.85^{\mathrm{c}}$ \\
\hline Means followed by the same letters do not differ from each other by the Tukey test at the level of $5 \%$ probability
\end{tabular}

AGK was not significant for all of the possible traits, as a portion of the variation occurred due to the KO. Data that were more concentrated in younger ages might also have influenced some of the results. Santana Júnior et al. (2008) and Tholon et al. (2001) believe that AGK did not influence the assessed traits due to the great number of primiparous goats making up their dataset. Pereira (2008b) provides a similar justification and states that concentrations of young goats (first and second kidding) in the herd would not allow for evidence of the AGK effect to be observed.

TDMY increased as AGK increased, and the opposite trend occurred in relation to $\mathrm{KO}$, which is theoretically contradictory. This may be linked to problems of multicolinearity generated by the joint analysis of these factors, in which $\mathrm{KO}$ corrects part of the AGK effect. If longer intervals between kiddings reduce overuse of the animals, it also helps older goats to produce more milk in relation to younger goats for the same kidding order, inasmuch as this effect was also included in the model. There is a tendency of using AGK only in genetic evaluations of TDMY, while avoiding the use of KO. This is because AGK corrects effects of $\mathrm{KO}$ and variation within the same kidding order, which is caused by age variation. This choice reduces the size of the incidence matrix for fixed effects and may contribute to reduce its multicolinearity; therefore, it may contribute to the precision and accuracy of the genetic evaluation.

TDMY presented its production peak around 38 days after the beginning of lactation, with an inflection point at approximately 150 days. DIM represents one of the most important factors to consider when TDMY is analyzed, and must be included as a 3-degree covariable in TDMY evaluations in test day models. It is used as a control variable in random regression models and the degrees of this factor may present a significant effect by the least squares method together with the estimate of the model error, which indicates the most fitted degree for the fixed curve of random regression models by using orthogonal polynomials.

\section{CONCLUSION}

Various factors significantly influenced each assessed trait studied. The factors that significantly influenced each trait in relation to Alpine and Saanen goats varied as well. 
To perform a proper genetic evaluation, the assessed traits and the model of analysis should be accounted for as well as previously evaluated factors that influence the traits analyzed, which should be included as correction factors in the model.

\section{REFERENCES}

Barbieri ME, Vasconcelos ASE, Simplicio AA and Figueiredo EAP (1990). Avaliação Produtiva de Cabras Leiteiras das Raças Saanen, Parda Alpina e Anglo-Nubiana. In: Reunião Annual da Sociedade Brasileira de Zootecnia Campinas, Anais, Piracicaba, 408.

Barbosa PF, Cruz GM, Cruz GM, Costa JL, et al. (1999). Causas de variação da produção de leite em um rebanho da raça Holandesa em São Carlos, SP. Rev. Bras. Zootec. 28: 974-981.

Brito LF, Silva FG, Angelini MS, Menezes GRO, et al. (2009). Fatores Ambientais e Genéticos que Influenciam os Teores dos Componentes do Leite de Caprinos da Raça Saanen. Associação Brasileira de Zootecnistas, Águas de Lindóia.

Carvalho G, Freitas AF, Valente J and Azevedo PCN (2001). Fatores de ajustamento da produção de leite, de gordura e de proteína para idade em bovinos mestiços europeu-zebu. Arq. Bras. Med. Vet. Zootec. 53: 714-719.

IBGE (2007). Censo Agropecuário 1940/2006. Até 1996 Dados Extraídos de: Estatística do Século XX. IBGE, Rio de Janeiro.

Pereira RJ, Melo ALP, Santana Júnior ML, Brito LF, et al. (2008a). Parâmetros Genéticos para Composição do Leite e Contagem de Células Somáticas de Caprinos da Raça Alpina. In: VII Simpósio Brasileiro de Melhoramento Animal, São Carlos.

Pereira RJ, Santana Júnior ML, Melo ALP, Menezes GRO, et al. (2008b). Fatores Ambientais que Influenciam Características Produtivas de Cabras da Raça Pardo Alpina. In: VII Simpósio Brasileiro de Melhoramento Animal, São Carlos.

Prata LF, Rezende KT, Carvalho MRB, Ribeiro SDA, et al. (1998). Composição, perfil nitrogenado e características do leite caprino (Saanen): Região Sudeste, Brasil. Ciênc. Tecnol. Aliment. 18: 1-8

Ribeiro AC (1997). Estudo dos Efeitos Genéticos e de Ambiente Sobre Características de Importância Econômica em Caprinos da Raça Saanen. Dissertação. Faculdade de Ciências Agrárias e Veterinária. Universidade Estadual Paulista, Jaboticabal.

Rodrigues JM, Rodrigues RA, Justino FB, Costa LC, et al. (2010). Efeitos locais e de larga escala na dinâmica climática do município de Viçosa. Soc. Nat. 22: 593-610.

Sands M and McDowell RE (1978). The Potential of the Goat for Milk Production in the Tropies. Cornell University, Ithaca, 39.

Santana Júnior ML, Melo ALP, Pereira RJ, Silva FG, et al. (2008). Influência de Fatores Ambientais na Porcentagem dos Componentes do Leite de Caprinos da Raça Alpina. In: VII Simpósio Brasileiro de Melhoramento Animal, São Carlos.

SAS Institute Inc. (2003). Statistical Analysis System User's Guide. Version 9.1. SAS Institute, Cary.

Silva VN, Rangel AHN, Braga AP, Maia MS, et al. (2009). Influência da raça, ordem e ano de parto sobre a produção de leite caprino. Acta Vet. Bras. 3: 146-150.

Soares Filho G, McManus C and Mariante AS (2001). Fatores genéticos e ambientais que influenciam algumas características de reprodução e produção de leite em cabras no distrito federal. Rev. Bras. Zootec. 30: 133-140.

Tholon P, Queiroz SA, Ribeiro AC, Resende KT, et al. (2001). Estudo genético quantitativo da produção de leite em caprinos da raça Saanen. Arch. Latinoam. Prod. Anim. 9: 1-5.

Vasconcellos BF, Pádua JT, Muñoz MFC and Tonhati H (2003). Efeitos genéticos e ambientais sobre a produção de leite, o intervalo de partos e a duração da lactação em um rebanho leiteiro com animais mestiços, no Brasil. Rev. Univ. Rural Sér. Ci. Vida Seropédica 23: 39-45. 